(c) Group of authors, 2019

UDC 616.711.6:004.932.72

DOI - https://doi.org/10.14300/mnnc.2019.14120

ISSN - 2073-8137

\title{
QUANTITATIVE CHARACTERISTIC OF INTERVERTEBRAL DISCS IN AGE ASPECT
}

Komleva N. E. ${ }^{1}$, Yakovlev N. M. 1, Danilov A. N. ${ }^{1}$, Chekhonatsky A. A. ${ }^{2}$, Tepeeva Yu. A. ${ }^{2}$, Badavi A. K. ${ }^{3}$

1 Saratov Scientific Research Institute of Rural Hygiene, Russian Federation

2 Saratov State Medical University named after V. I. Razumovsky, Russian Federation

3 Polenov Neurosurgical Institute of Almazov National Medical Research Center, Saint-Petersburg, Russian Federation

\section{КОАИЧЕСТВЕННАЯ ОЦЕНКА МЕЖПОЗВОНКОВЫХ АИСКОВ В ВОЗРАСТНОМ АСПЕКТЕ}

Н. Е. Комлева ${ }^{1}$, Н. М. Яковлев ${ }^{1}$, А. Н. Аанилов ${ }^{1}$, А. А. Чехонацкий ${ }^{2}$, Ю. А. Тепеева ${ }^{2}$, А. К. БаАави ${ }^{3}$

1 Саратовский научно-исслеАовательский институт сельской гигиены, Российская ФеАерация

2 Саратовский госуАарственныЙ МеАицинский университет им. В. И. Разумовского, Российская ФеАерация

3 Российский научно-исслеАовательский нейрохирургический институт им. проф. А. А. Поленова - филиал Национального меАицинского исслеловательского центра им. В. А. Алмазова, Санкт-Петербург, Российская ФеАерация

The relevance of the study is determined by the high prevalence of back pain, which is due to discogenic pathology. The study aimed to study the quantitative characteristics and patterns of degenerative changes in the IVD of the lumbosacral spine in the age aspect. The visualization characteristic of the IVD of the lumbosacral spine based on the quantitative data in the age aspect is determined with the help of computer analysis. The statistical analysis revealed a moderate inverse correlation between the age of patients and the degree of degenerative changes in the IVD from $L_{1}-L_{2}$ to $L_{4}-L_{5}$ and a direct statistical average relationship between the degree of degenerative changes in all the IVD of the lumbosacral spine except for the disk $L_{5}-S_{1}$. The statistical connection was not found when comparing the degree of degenerative changes in this disc with the age of patients and degenerative changes in other lumbar discs of the lumbosacral spine, which was explained by the biomechanical features caused the maximum load on this disc.

Keywords: intervertebral disk, computer analysis, degenerative changes

Актуальность исследования определена высокой распространенностью боли в спине, зачастую вызванной дискогенной патологией. Цель исследования состояла в количественной оценке и изучении возрастных особенностей дегенеративно-дистрофических изменений межпозвонковых дисков (МПД) поясничного отдела позвоночного столба (ПОП).

С использованием компьютерного анализа получена информация о возрастных особенностях МПД ПОП, представленная в формате количественных данных. Показано, что степень выраженности дегенеративно-дистрофических изменений MПД c $L_{1}-L_{2}$ по $L_{4}-L_{5}$ имеет умеренную обратную корреляционную связь с возрастом; степень дегенеративно-дистрофических процессов всех исследуемых МПД находится в прямой статистически значимой умеренной связи. Исключение составляет диск $\mathrm{L}_{5}-\mathrm{S}_{1}$. При сопоставлении степени выраженности дегенеративно-дистрофических изменений данного диска с возрастом обследуемых и дегенеративно-дистрофическими изменениями других дисков ПОП корреляции не выявлено, что можно объяснить анатомо-физиологическими особенностями, образом жизни, условиями труда и пр.

Ключевые слова: межпозвонковый диск, компьютерный анализ, дегенеративно-дистрофические изменения

For citation: Komleva N. E., Yakovlev N. M., Danilov A. N., Chekhonatsky A. A., Tepeeva Yu. A., Badavi A. K. QUANTITATIVE CHARACTERISTIC OF INTERVERTEBRAL DISKS IN AGE ASPECT. Medical News of North Caucasus. 2019;14(3):494496. DOI - https://doi.org/10.14300/mnnc.2019.14120

Для цитирования: Комлева Н. Е., Яковлев Н. М., Данилов А. Н., Чехонацкий А. А., Тепеева Ю. А., Бадави А. К. КОЛИЧЕСТВЕННАЯ ОЦЕНКА МЕЖПОЗВОНКОВЫХ ДИСКОВ В ВОЗРАСТНОМ АСПЕКТЕ. МедИЦИнСКИЙ вестник Северного Кавказа. 2019;14(3):494-496. DOI - https://doi.org/10.14300/mnnc.2019.14120

IVD - intervertebral disc 
D egenerative changes in the intervertebral discs (IVD) are a common cause of back pain [1]. The assessment improving and the monitoring of the IVD have high scientific and practical importance [2]. Magnetic resonance imaging is the choice method of the IVD structures study in clinical practice [3]. However, the results of the researches are presented in the form of qualitative characteristics of the studied structures, which will complicate the diagnosis of pathological changes in the early stages and dynamic observation $[4,5]$. The program of the computer analysis of the digital magnetic resonance imaging of the IVD is developed to solve this problem [6]. The structures of the spine are identified and analyzed automatically with the help of this program.

The aim of the present study was to quantitative characteristics and the regularity of degenerative changes in the IVD of the lumbosacral spine in the age aspect.

Material and Methods. The content of the study consists of the digital magnetic resonance tomograms of the patients' lumbar-sacral spine from the Saratov Research Institute of Traumatology and Orthopedics to study the characteristics of imaging indicators of the IVD in the age aspect. All the studied tomograms were obtained on the magnetic tomograph APERTO HITACHI with the magnetic field level $0.4 \mathrm{TI}$ in $\mathrm{T} 2$ mode, with a value $T R=2.700 \mathrm{~ms}$ and $T E=120 \mathrm{~ms}$, a matrix $512 \times 512$.

The insertion criterion was the age of patients - from 21 to 72 years in the tomogram selection. We did not apply the exclusion criteria to ensure a high generality of the study results. Sixty two patients were selected consistently in the patient register who underwent the examination in the radiology department; they got a study of the lumbosacral spine and satisfied the insertion criterion. They were 27 men (44\%) and 35 women (56\%).

Then the digital MR tomograms of the lumbosacral spine of selected patients were extracted from the archive and copied to CD-disks for further analysis. The digital magnetic resonance tomograms of the lumbosacral spine were obtained in T2 mode in the sagittal plane passing through the center of the IVD.

During the computer analysis, 310 IVD was identified 258 (83.2 \%) disks, which formed microimages for a subsequent processing. At the same time, $52(16.8 \%)$ IVD were not included in the study that the sagittal plane passed outside the center of the studied objects due to posture disorders, and this fact complicated the analysis. Thus, the study included 258 microimages of the IVD.

Statistical data analysis was performed using Statistica 6.0 (StatSoft Inc, USA). Descriptive statistics of the quantitative characteristics are presented the average values and average quadratic deviation in the format $\mathrm{M} \pm \mathrm{s}$, the median, and quartiles in the form Me [LQ; UQ], the Kruskal - Wallis method was used for groups comparison, the Spearman criterion - for the analysis of the link characteristics.

Results and Discussion. The developed method of the computer analysis of the digital tomograms of the spine, the diagnostic of which is proved in the course of preliminary studies, allows to obtain an objective characteristic of each IVD on a set of characteristic features: the average brightness of the gray level and the standard deviation of intensity from the grayscale, the height and width of the disk, the angle of inclination about to the horizontal line and the shape of the disc [7]

At the first stage of the study, we compared the values of the average brightness of the gray level between the similar IVD belonging to men and women: $L_{1}-L_{2} ; L_{2}-L_{3}$; $L_{3}-L_{4} ; L_{4}-L_{5} ; L_{5}-S_{1}$ using the nonparametric test of Kruskal-Wallis. This analysis showed no statistically signifi- cant difference. Besides, we compared the total average brightness of the gray level on all disks in the groups of men and women, which also refuted the statistically significant difference between the studied objects $(p=0.06)$. The obtained results allow further analysis of the IVD status without taking the gender.

We studied the relationship between the severity of degenerative changes in the IVD and age using the nonparametric correlation analysis of Spearman. The intensity of degenerative changes in the IVD was established in the course of computer analysis by the summation of the average brightness indicators of the gray level of all the IVD of the lumbosacral spine $\left(L_{1}-L_{2}, L_{2}-L_{3}, L_{3}-L_{4}, L_{4}-\right.$ $\left.L_{5} \cup L_{5}-S_{1}\right)$. The inverse statistically significant moderate correlation was established $(r=-0.53 ; p<0.001)$.

Table 1 presents the data of the correlation analysis by Spearman of the studied parameters differentiated by all the studied IVD.

Table 1

Analysis of the correlation between the age and the average brightness of the gray level of the IVD

\begin{tabular}{|c|c|c|c|c|c|}
\hline \multirow{2}{*}{$\begin{array}{c}\text { Spearman's } \\
\text { coefficient, } \\
\text { value p }\end{array}$} & \multicolumn{5}{|c|}{ Examined intervertebral discs } \\
\cline { 2 - 6 } & $\mathrm{L}_{1}-\mathrm{L}_{2}$ & $\mathrm{~L}_{2}-\mathrm{L}_{3}$ & $\mathrm{~L}_{3}-\mathrm{L}_{4}$ & $\mathrm{~L}_{4}-\mathrm{L}_{5}$ & $\mathrm{~L}_{5}-\mathrm{S}_{1}$ \\
\hline $\mathrm{r}$ & -0.48 & -0.49 & -0.52 & -0.49 & 0.44 \\
\hline $\mathrm{p}$ & 0.006 & 0.006 & 0.003 & 0.001 & 0.32 \\
\hline
\end{tabular}

Thus, the moderate inverse correlation between the age and the severity of degenerative changes of intervertebral discs (the average brightness of the gray level) from $L_{1}-L_{2}$ to $L_{4}-L_{5}$ was established [8]. The relationship between the age and the average brightness of the gray level of the IVD $L_{5}-S_{1}$ was not revealed, it could be explained evidently by biomechanical features, resulting in a high load on this disk [9]. So, the IVD $L_{5}-S_{1}$ is at the maximum risk of degenerative changes and the pathological processes in it are ahead of similar operations in other disks $[10,11]$. Therefore, degenerative changes in $L_{5}-S_{1}$ can be observed already in young people.

A similar pattern was found in the study of the correlation between the average brightness level of the IVD of the lumbosacral spine. The state of the IVD $L_{5}-S_{1}$ does not correlate with other studied disks by comparing the average brightness of the gray level. A direct statistical moderate relationship between the other discs (from $\mathrm{L}_{1}$ $L_{2}$ to $L_{4}-L_{5}$ ) was established according to this indicator (Table 2) by the correlation analysis using the Spearman nonparametric method.

Table 2

Analysis of the correlation of the average brightness level between the lumbosacral IVD ( $r$, the Spearman's method)

\begin{tabular}{|c|c|c|c|c|c|}
\hline & $L_{1}-L_{2}$ & $L_{2}-L_{3}$ & $L_{3}-L_{4}$ & $L_{4}-L_{5}$ & $L_{5}-S_{1}$ \\
\hline$L_{1}-L_{2}$ & & $0.71 *$ & $0.63 *$ & $0.34 *$ & 0.47 \\
\hline$L_{2}-L_{3}$ & $0.71 *$ & & $0.49 *$ & $0.39 *$ & 0.11 \\
\hline$L_{3}-L_{4}$ & $0.63 *$ & $0.49 *$ & & $0.51 *$ & 0.37 \\
\hline$L_{4}-L_{5}$ & $0.34 *$ & $0.39 *$ & $0.51 *$ & & 0.41 \\
\hline$L_{5}-S_{1}$ & 0.47 & 0.11 & 0.37 & 0.41 & \\
\hline
\end{tabular}

* Statistically significant correlations.

To determine the visualization indicators was characterizing the state of the IVD in the age aspect. It is advisable to analyze their state in age groups differentially since discs are undergone irregularly throughout the spine by degenerative processes. Distribution by age 
groups was carried out following the classification adopted at the VII All-Union Conference on age morphology, physiology, and biochemistry (Moscow, 1965). The average brightness of the gray level in the group, the standard deviation, the median, the upper and lower quartiles were determined for each age group (Table 3 ).

Table 3

Indicators of the average brightness of the gray level of the intervertebral discs in different age groups

\begin{tabular}{|c|c|c|c|}
\hline $\begin{array}{c}\text { Studied } \\
\text { indicators }\end{array}$ & $M \pm s$ & Me [LQ; UQ] & $\begin{array}{c}\text { p-value for the } \\
\text { Kruskal - Wallis's } \\
\text { criterion }\end{array}$ \\
\hline Mature age I & $71.4 \pm 18.4$ & $\begin{array}{c}74[57 ; \\
86.5]\end{array}$ & \multirow{3}{*}{$\begin{array}{l}p_{1-2}=0.001 \\
p_{2-3}=0.006 \\
p_{1-3}<0.001\end{array}$} \\
\hline Mature age II & $57.8 \pm 17.9$ & $55[42 ; 74]$ & \\
\hline Advanced age & $44.9 \pm 11.4$ & $42[38 ; 46]$ & \\
\hline
\end{tabular}

Note: $\mathrm{p}_{1-2}$ is the level of statistical significance by comparing the average brightness of the grayscale in the groups «mature age |» and «mature age II»; $p_{2-3}$ is the level of statistical significance by comparing the average brightness of the grayscale in the groups «mature age II» and «advanced age»; $p_{1-3}$ is the level of statistical significance by comparing the average intensity of the grayscale in the groups «mature age |» and «advanced age».
A comparison of three independent groups using the Kruskal - Wallis nonparametric test allowed establishing a statistically significant difference between all groups. At the same time, the average brightness of the gray level decreased with age increase. These results are expected hypothetically and adequate, however, they are provided in quantitative values for the first time [12].

Conclusions. The visualization characteristic of the IVD of the lumbosacral spine based on quantitative data in the age aspect is determined with the help of computer analysis. The statistical analysis revealed a moderate inverse correlation between the age of patients and the degree of degenerative changes in the IVD from $L_{1}-L_{2}$ to $L_{4}-L_{5}$ and a direct statistical average relationship between the degree of degenerative changes in all the IVD of the lumbosacral spine except for the disk $L_{5}-S_{1}$. No statistical connection was found by comparing the degree of degenerative changes in this disc with the age of patients and degenerative changes in other lumbar discs of the lumbosacral spine, so it was explained by biomechanical features that caused the maximum load on this disc.

Disclosures:

The authors declare no conflict of interest.

\section{References}

1. Tavakoli J., Costi J. J. Development of a rapid matrix digestion technique for ultrastructural analysis of elastic fibers in the intervertebral disc. J. Mech. Behav. Biomed. Mater. 2017;71:175183.

https://doi.org/10.1016/j.jmbbm. 2017.03.014

2. Michopoulou S., Costaridou L., Panagiotopoulos E., Speller R., Panayiotakis G. [et al.] Atlas-based Segmentation of Degenerated Lumbar Intervertebral Disc from MR Images of the Spine. IEEE Trans. Biomed. Eng. 2009;56:22252231. https://doi.org/10.1109/TBME.2009.2019765

3. Han Z., Wei B., Mercado A., Leung S., Li S. Spine-GAN: Semantic segmentation of multiple spinal structures. Med. Image Anal. 2018;50:2335 https://doi.org/10.1016/j.media.2018.08.005

4. Alomari R. S., Corso J. J., Chaudhary V., Dhillon G. Computer-aided Diagnosis of Lumbar Disc Pathology from Clinical Lower Spine MRI. Int. J. Comput. Assist. Radiol. Surg. 2010;5:287293. https://doi.org/10.1007/s11548-009-0396-9

5. Michopoulou S., Costaridou L., Vlychou M., Speller R., Todd-Pokropek A. Texture-based Quantification of Lumbar Intervertebral Disc Degeneration from Conventional T2weighted MRI. ActaRadiologica. 2011;52:9198. https://doi.org/10.1258/ar.2010.100166

6. Komleva N. E., Daurov S. K., Bolshakov A. A., Glazkov V. P., Bakutkin V. V. [et al.] Computer program for analyzing digital magnetic resonance tomography of lumbosacral part of spine. Journal of New Medical Technologies. 2012;19(1):192195
7. Komleva N. E., Rebrova O. Yu., Daurov S. K., Maryanovskky A. A. The method of determining the degrees of degenerative changes in intervertebral discs at computer analysis of digital magnetic and resonance tomography. Journal of New Medical Technologies. 2012;19(1):195197.

8. Tarukado K., Ono T., Tono O., Tanaka H., Ikuta K. [et al.] Does Modic Change Progresss With Age? SPINE. 2017;42(23):18051809. https://doi.org/10.1097/BRS.0000000000002254

9. Danilov A. N., Komleva N. E., Yakovlev N. M. Computer analysis of spinal magnetic resonance tomograms in occupational medicine. Russian Journal of Occupational Health and Industrial Ecology. 2017:9:5960.

10. Guo R., Yang X., Zhong Y., Lai Q., Gao T. [et al.] Correlations between Modic change and degeneration in 3-complex of the lower lumbar spine: A retrospective study. Medicine (Baltimore). 2018;97(38):e12496.

https://doi.org/10.1097/MD.0000000000012496 Available at: https://www.ncbi.nlm.nih.gov/pmc/articles/ PMC6160214/Accessed May 24, 2019.

11. Jiang S., Li W. Biomechanical study of proximal adjacent segment degeneration after posterior lumbar interbody fusion and fixation: a finite element analysis. J. Orthop. Surg. Res. 2019;14(1):135 https://doi.org/10.1186/s13018-019-1150-9

12. Isaikin A. I., Ivanova M. A., Kavelina A. V., Chernenko O. A. Lumbar discogenic pain. Neurology, neuropsychiatry, psychosomatics. 2016;8(3):8894.

https://doi.org/10.14412/2074-2711-2016-3-88-94

\section{About authors:}

Komleva Natalia Evgenievna, DMSc, Head of Department of preventive medicine and innovative technologies; tel.: +79172170767; e-mail: NEKomleva@yandex.ru

Yakovlev Nikolai Mikhailovich, Physician; tel.: +784529278-90; e-mail: niusgsar@mail.ru

Danilov Alexey Nikolaevich, DMSc, Director; tel.: +78452927890, e-mail: niusgsar@mail.ru

Chekhonatsky Andrey Anatolyevich, DMSc, Head of the Department of neurosurgery named after E. I. Babichenko;

e-mail: niusgsar@mail.ru

Tepeeva Julia Aleksandrovna, Lecture of the Foreign Languages Department; e-mail: niusgsar@mail.ru

Badavi Akhmed Kayed Mayhub, postgraduate student;

tel.: +79185013486; e-mail: drakmb@yandex.ru 